\title{
下顎枝矢状分割のねじ固定に際しての簡便な 下顎枝外側板の位置決定法とその評価
}

\author{
三村保・宅間政次・東豊・西＼cjkstart正寛 \\ 野添悦 郎
}

\section{The practical method and its results to decide the precise position of the ascending ramus for the bicortical screw fixation in sagittal split osteotomy}

\author{
Tamotsu Mimura - Masatsugu Takuma - Yutaka Azuma \\ Masahiro Nishi • Etsuro NozoE
}

\begin{abstract}
The bicortical screw fixation of the ascending ramus in sagittal split osteotomy presents many advantages, such as the short period of intermaxillary fixation, the diminution of relapse and so on. To secure successful results in the maneuver, the most important procedure is to settle the lateral fragment of ascending ramus in a precise position at the time of fixation. A facile technique was contrived and applied to eighteen cases of sagittal split.
\end{abstract}

The method is as follows:

1. Just prior to splitting, intermaxillary ligation is performed in order to fix the ascending ramus at the position of central occlusion.

2. A V-shaped notch is engraved on the anterior edge of the ascending ramus at the level of the maxillary dental arch.

3. A flexible metal frame for Schuchardt-Schiene is adjusted such that the terminal hook may fit to the notch and two or three hooks are plunged into the interdental spaces of the maxillary arch. Thus the position of the ramus is surveyed using the maxillary teeth as the landmarks.

4. After splitting, intermaxillary ligation is performed again. The metal frame is adjusted to the maxillary arch. The notch of the lateral ascending ramus is fitted to the terminal hook. Thus the lateral ascending ramus is settled in the same position before splitting.

5. Both fragments are fixed using metal or sapphire screws in the manner described elsewhere.

The divergence in the position of the ascending ramus was analysed in seventeen cases. The goniometrical differences of the ascending ramus were estimated by superim posing lateral $\mathrm{X}$-ray films obtained in pre- and postsurgical stage.

The values were very small ranging from 1 degree to 10 degrees with an average of 3.9 degrees. Neither severe symptoms, such as longstanding pain and trismus, nor functional disturbances were observed clinically.

Key words: sagittal split osteotomy, bicortical screw fixation, positioning of ramus

鹿児島大学菌学部第 2 口腔外科学講座

(主任：三村 保教授)

Second Department of Oral and Maxillofacial
Surgery, Kagoshima University Dental School

(Chief: Prof. Tamotsu Mimura)

受付日：昭和61年 3 月 6 日 
緒

\section{言}

下罘枝矢状分割骨切り術の骨片固定をねじ止めで行う 方法は，鋼線による結紮に較べ，治癒が速く顎間固定期 間が著しく短縮できる，術後骨片間のずれがないため後 戻りが少ない等，多〈の利点を有する1,2) 一方，本法 の難点としては，手術後は下靧位置の調整が不可能なこ と，そのために固定の際に下顎枝外側板を適正な位置に 設定する手順が必要で，むしこれを省いてねじ止め固定 を行うと影関節に種々の障害をきたす扣それがあるこ と、ねじ止め固定の手順に若干の慣れを要することなど があげられる、それゆ立に，簡便で確実な方法によって 外側板の位置決定を行らことができれば，本法を行ら上 でのメリットは大きい

われわれは，1981年より副子用金属線を用いた簡便な 位置決定方法を考案施行し，良い結果を得ている．今 回，われわれの行っている方法拉よび，本法を行った場 合の下䫇枝外側板の術前後における位置のずれを検討し た結果について報告する。

\section{位置沠定ならびに固定の方法}

術式の基本：下顎枝分割の直前に，中心咬合位にて上 下顎間結禁固定を施し，その時の下顎枝外側板の位置を 上䫑歯列を基準として記録して拉く，分割終了後，骨体 部を新たな中心咬合位に执いて強固汇䫇間結紮固定を施 し，下顎枝外側板を分割直前の位置に正確に戻して内外 両側板をねじで固定する。
手 順 :

1）買間結柴固定供え上下歯列には予めシューハル トシーネを装着しておく，矯正用唇側弧線装置が装着さ れている場合は，それを利用することもできる，通法に 従い手術を進め，矢状分割の直前に中心咬合位で上下顎 間結㮡固定を行う。この時の買間結柴は $0.3 \mathrm{~mm}$ 結柴 用鋼線を用い， 3 䈯所程度で良い，

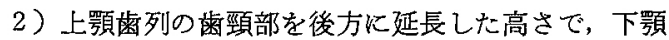
枝前縁にフィッシャーバーを用いて樑さ $3 \sim 4 \mathrm{~mm}$ の切 れ込みをいれる(図 1).

3）シューハルトシーネ用金属線を用い，端のフック (枝線) を下顎枝前縁の切痕に適合させた後, 前方部の フックの $2 \sim 3$ 本が上䋶大日歯から小曰霜部の歯間乳頭 部の空隙可度嵌入するよう, フックの角度・形状をプ ライヤーで調整する，これによって上靧歯牙を基準とし た上行枝前縁の位置が記録される，金属線を変形させな い上万取り出す。対側も同様行行う（図2，5）.

4）䫇間固定を除去し，矢状分割を完了する。

5) 所定の位固に下顎骨体部を移動し, 所期の咬合状 態を得たら強固に頱間固定を行ら。固定は $0.4 \mathrm{~mm}$ 鋼 楾で $5 \sim 6$ 籄所程度必要である（図 $3 \mathbf{a} ， 6$ ).

6）位置記録に用いたシューハルトシーネ用金属線を 上顗歯列㳖着する，歯間空隙に正しくフックを嵌入し た後，上顎歯列に装着したシーネまたは矯正用弧線に鋼 線で結柴し安定をはかる。

7) 下靧枝外側板の切痕と端のフックを適合させる (図 3 b).

8）外側板を動かさないよう固定したまま，通法に従 いねじ固定を行う。片側に 2 本の $\mathrm{AO}$ 金属ねじをたはサ
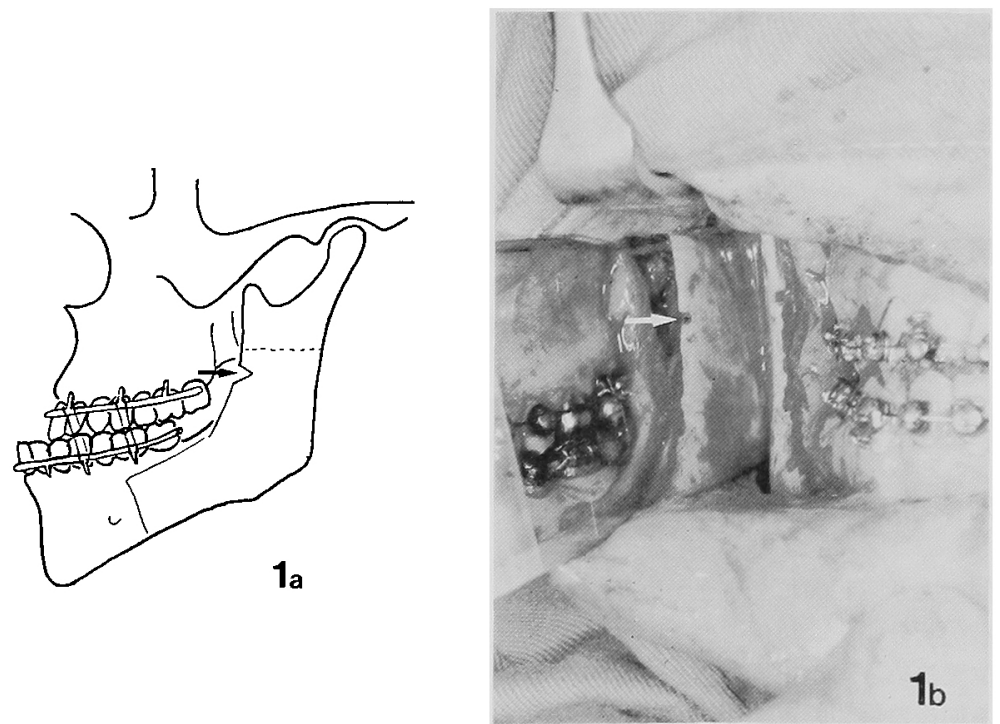

図 1-a， b 知分割直前に中心咬合位で上下䫇間結禁固定を施す、下顎枝前緑 に切れ込みを入れる。（矢印） 

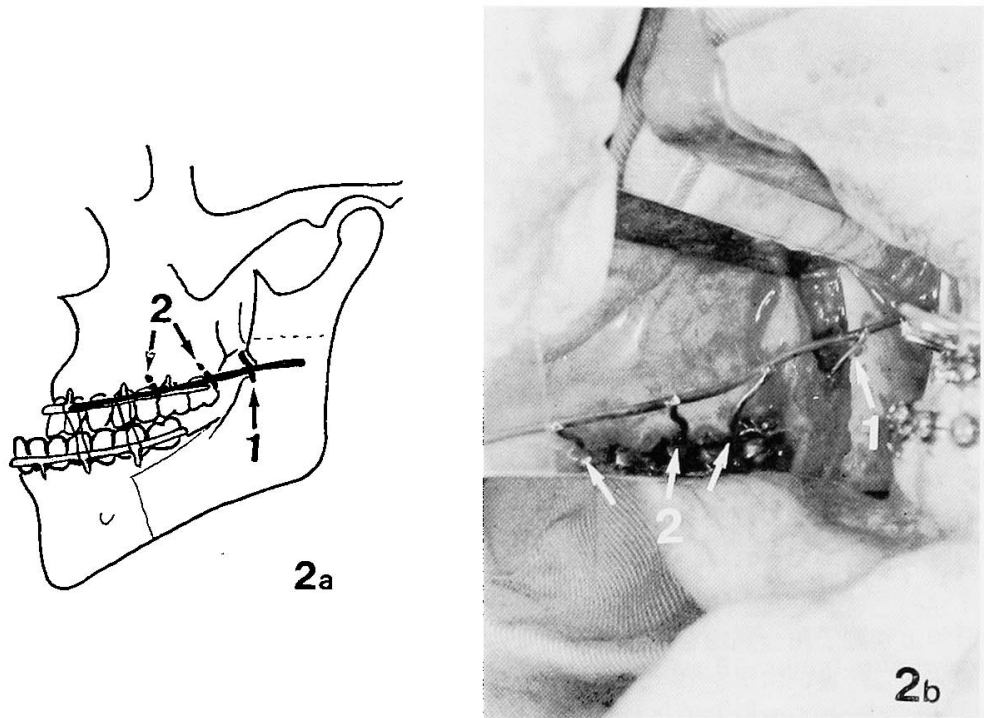

図 2-a， b シューハルトシーネ用金属線を用い, 端のフックを前縁の切れ込み に適合させた後, 前方部のフックを調整し, 上顎菌列の荬間空隙に 嵌入させる。（矢印1は切れ込みに適合したフック，矢印 2 は歯間 空隙に入ったフック)
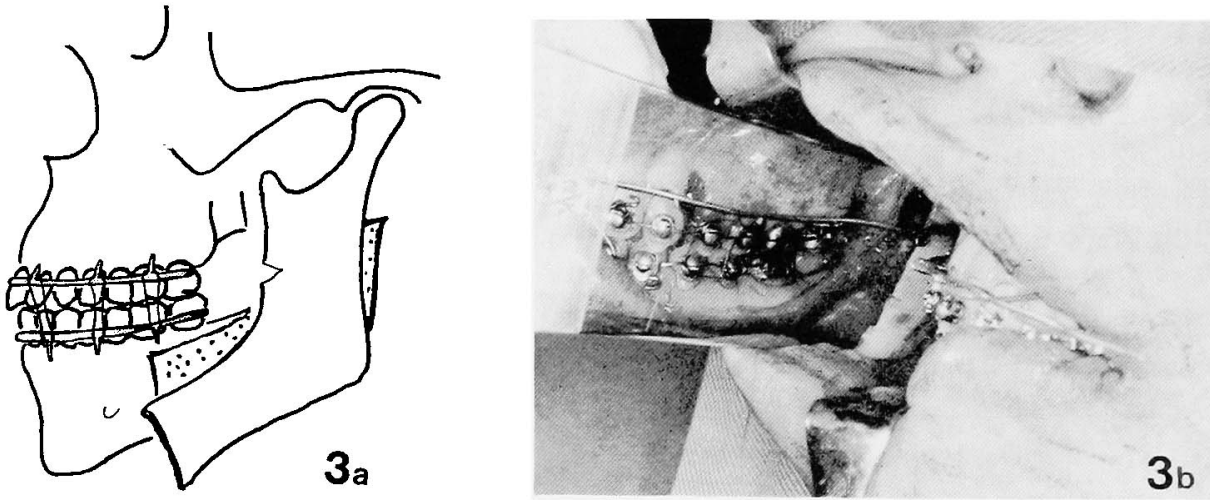

図 $3 a$ : 靧間固定解除後, 矢状分制を終了し所期の咬合状態を得たら, 再度強固 な䫇間固定を施す。

b：金属線を上䫇递列に適合した後，切れ込みを端のフックに適合する。

ファイアねじを用いる（図 4,7).

\section{対象ならびに結果}

昭和56年当講座開設より昭和 60 年 8 月までの 4 年 5 か 月間に行った下顠枝矢状分割法は18例で，そのすべてに 上記の方法による位置決めと固定を行った．手術内容と 結果は表 1 に示す，術後の䅡間固定は16〜31日，平均20 日間行った。䫇間固定期間中に钼関節部に疼痛を訴えた 例はなかった，顎間固定解除後は比較的早期に大開口が
可能となり，長期にわたって開口障害や闑口時疼痛等を 訴えた者は皆無であった，顎間固定解除直後に開口時疼 痛を訴えたもの3 例, 雑音を認めたもの 1 例があった がここれらいずれる 3 か月以内に消失した。

下顎枝外側板の位置変化の険討 : 術後 3 ないし 5 日目 の側方 X線規格写真のトレースを術前のむのと重ね合 わせることによって, 術前術後の下顠枝外側板の角度の ずれを测定した，下䫇枝の形態は個人差が著しく，角度 の計測にあたっての基準線を設定することが難しい．そ こで, 術後の下顎枝外側板と術前の下顡枝とを正確に重 

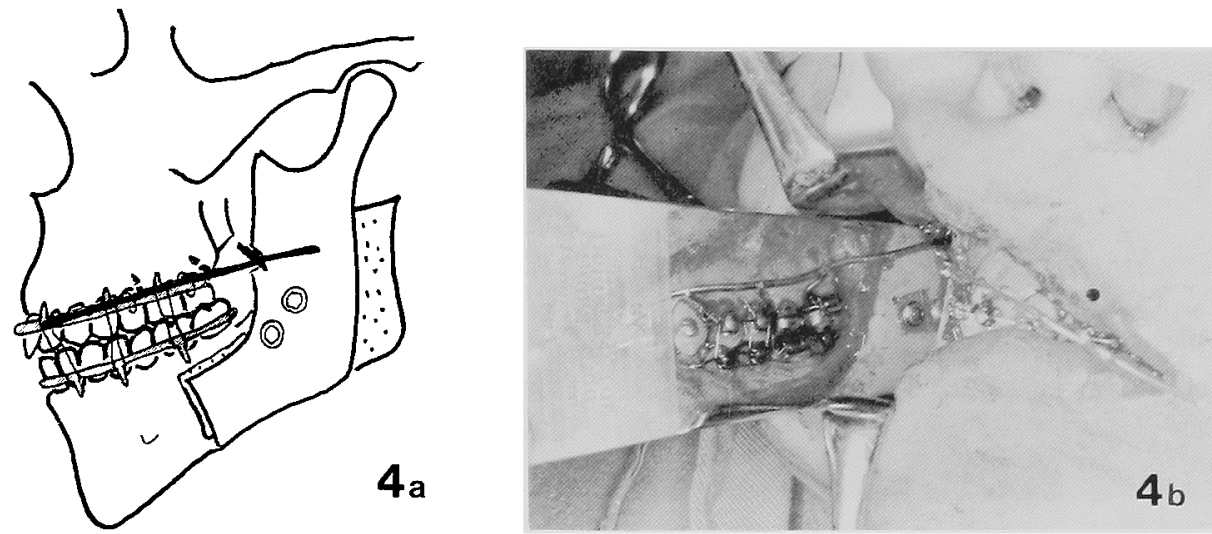

図 4-a，b衫じ固定を行う.

表 1 症例・手術内容扰よび結果の一覧

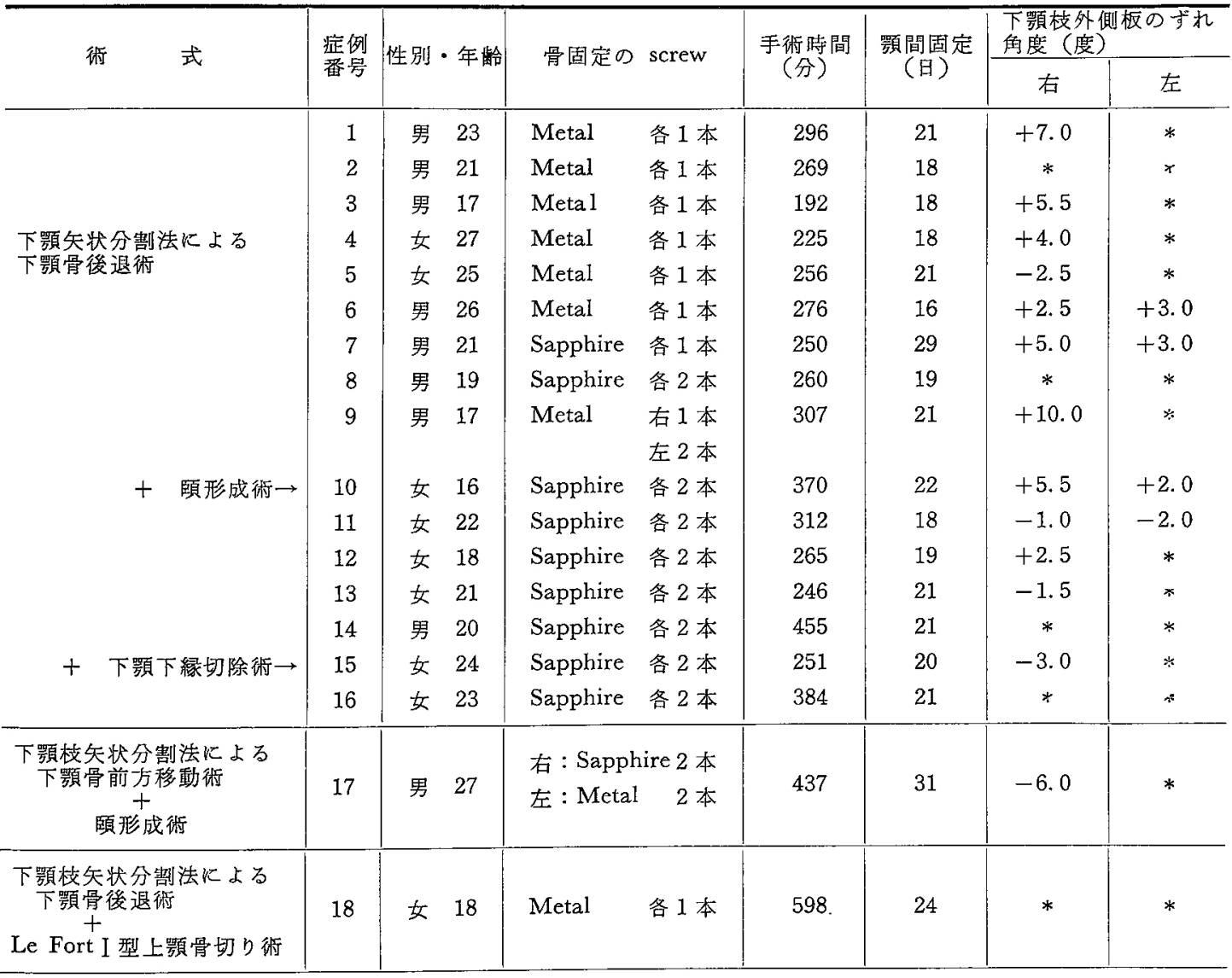

症例番号 $1 \sim 160$ 平均

288

20

十は術前より後方への偏位，一は前方への存位を示方。

*は輪郭が不明暸でトレースできなかったもの 


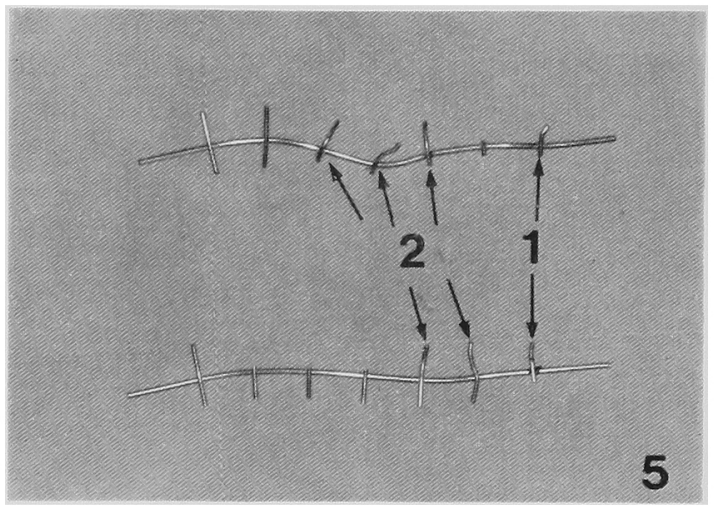

図 5 口腔外にとり出した金属線. 主線は手指で容 易に曲げることができる。フックはプライヤ ーで曲げる。（1は切れ込みに，2は齿間空 隙に入る)

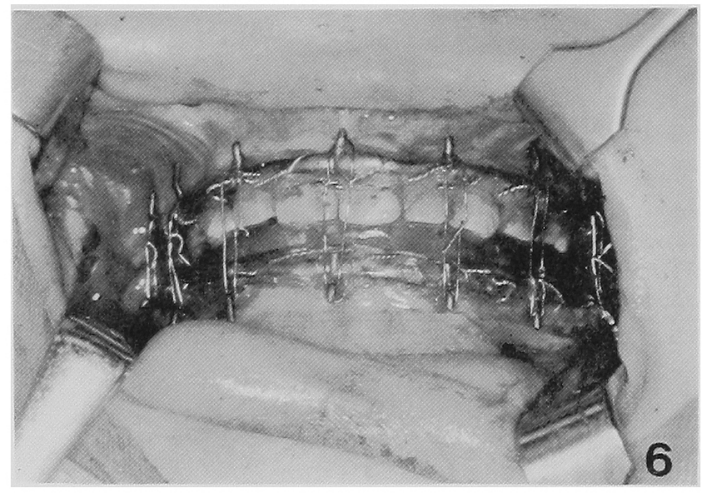

図 6 ねじ固定の際の䫑間固定は強固に行ってお く、矯正用弧線よりもこのよ5なシ_ーハル トシーネの方が安心である。本例では bite splintを仵用している。

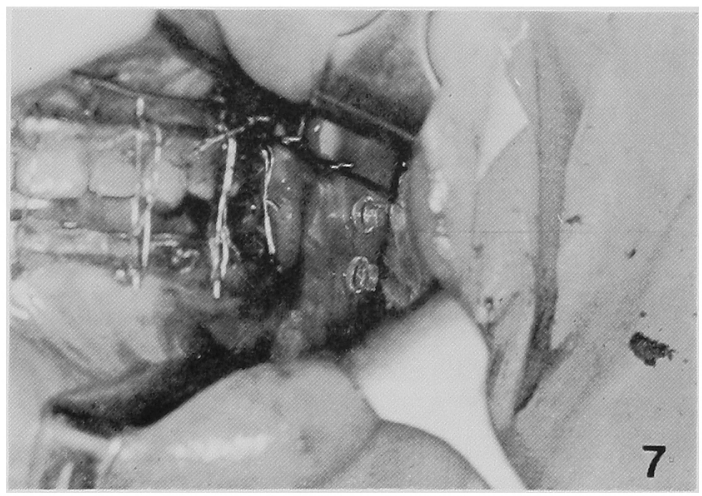

図7サファイアねし2 2 本による固定を示す,
わ合わせた時の S-N 平面のなす角をるって表した。

明確にトレースできたのは 17 関節であった（表1）. 表中十で示したものは術後の外側板の位置が術前より後 万にずれていたすので，一は前方へずれていたものであ る. 最大 10 度, 最小 1 度, 平均 3.9 度で術前術後に括け る下買枝外側板の位置のずれはきわわて軽微であった.

\section{考}

察

下顎枝矢状分割の骨片固定に㸚じを用いる方法は， Spiessle ${ }^{2)}$ によって考案され，その後 Souyris ${ }^{4}$ ，松浦 $ら^{5)}$ ，三村ら ${ }^{1)}$ にってその利点加確認されている。す なわち正確な位置決めの後にねじ止め固定を行ら方法 は，鋼線による固定に較べて以下の利点を有する.

○術後の顝間固定が著しく短縮できる.

○術後の骨片間のずれによる後厌りがない.

○口腔内の創の閉鎖が速やかに営まれるため感染のお

それがなく，早期より経口摄取が可能である.

○術後速やかに大開口が可能である。

○顎間固定に耐方る歯牙がない例や総義歯症例でる安 定した結果が得られる。

○術直後に技管や口腔内吸引のために開口しても下顠 位置がずれない.

しかし，術後は外側板と骨体部の位置関係を変えるこ とができないため，固定の際の外側板の位置が適切でな かった場合には，開口制限や顎関節部の疼痛，開口時の 下顎の偏位などの障畫を術後に㶐起する可能性が考えら れる。さらに，ねじを用いることによる下歯槽神経損傷 の可能性, 小さいとはい文皮切を要する, 手順がやや順 雅なども難点としてあげられる.

ねし固定の長所を活かし，かつ術後に障害を起こさな いために最す大切なことは，術後の中心埧合位における 下顛枝外側板の位置が術前と同一の位圆になるよう固定 することである. Schmoker ${ }^{32}$ は Simulography と呼ぶ 装置を考案している。これは，咬合器と目盛りをつけた 透明プラスチック板とを組み合わせて，術前術後の下蕷 石垶模型の位置のずれを真横から定量的に測定でさるよ

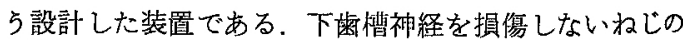
位置を決める上では役立つとしてる，外側板の位置を術 中に正確に再現することはきわめて難しいと思われる。

松浦ら゙は，プラスチック板をつけた弧線装圆を上罘 列に装着し，これと下罘枝外側板とをミニテュアプレ ートで固定することによって，術前の中心咬合位の位置 を記録する方法を教案し，発表している，きわめて実用 的で勝れた方法と思われる。われわれが行っている万洗 も基本的には同じ着腿であるが，手術室に常に用意され ているシューハルトシーネ用金属を定規として用いるこ とによって，より簢单かつ速やかな再現がでさる利点が ある。松浦の方法と巽なり，外側板の切痕に前縁を环接 
し，固定する方法をとっているため術中に後方にずれる 可能性がないとは断言できないが，ドリル穿孔時やねじ 山切りの際にずれないよう配虑することによって満足で きる結果が得られた。

ねじ止め固定直後の下罘真枝外側板の偏位量を検討した 研究は少ない，瀬戸ら ${ }^{6)}$ は 3 例の側斜方向 X線規格写真 のトレース上で内耳道を重㸚合わせ, 術後関節頭が前方 へ偏位する傾向を認めている。

今回われわれは, 術直後の側方規格X線写真のトレー スと術前のそれとを重ね合わせて，ずれを測定した。測 定に当たって下顎枝外側板上に基準点または基準線を設 定することが望ましいが，分割後は輪郭が暖昧となって 判定が難しい，そこで，術前術後の下靧枝外側板の外形 を正確に重㸚合わせた時の $\mathrm{SN}$ 平面のなす角をもって表 した.

術後定期的にX線撮影を行って経過観察を行うと，分 割部の両骨片は急速にその形態を変えていくことがわか る。したがって，術後日時を経ると，位置のずれによる ものか, 術後の形態変化によるものかが判定出来なくな るのみならず，形態変化のために重㸚合わせが不可能と なる.

今回，われわれは術後 3 日ないし 5 日の間に撮影した フィルムと術前のそれとを比較することによって, 位置 のずれを測定した。この時期のX線フィルム上では下靧 枝外側板はその輪郭が最も鮮明にトレースできる。

トレースできた17関節についての結果は, 平均 3.9 度 で最大 10 度が 1 件, 5 度以上 5 件で, 11 件が 4 度以下の ずれにとどまり，きわめて正確な再現がなされているこ とがわかる. 臨床所見においても術後䫇関節部の自発痛 や長期にわたる開口障害をきたした例はなく, 顎間固定 解除後一過性に開口時疼痛または雑音を生じたもの 4 例 があったが，いずれも術後 3 か月以内に消失し，きわめ て良い結果が得られた。

本法を行った場合には, 二度の頧間結柴を含む位置決 め, ねじ止めなどの操作のために手術時間がやや延長す る. 今回の症例は熟達度の異なる術者 4 名が行ったもの すべてをあげたが，顎骨後退術のみを行った場合の平均 所要時間は 4 時間半 (288分) で, 道ら ${ }^{7)}$ の囲繞結柴の約 3 時間 (174分), 飯塚ら ${ }^{8)}$ の 3 時間11分よりも約 1 時間 30 分程長〈かかっている。 しかし松浦ら ${ }^{5)}$ も指摘してい るように位置復元法を用いたねじ止め固定法のメリット
は， 1 時間半ないし 2 時間の手術時間の延長を補ってあ り余ると考える.

\section{結語}

下顎枝矢状分割骨切り術のねじ止め固定に際しての下 罰枝外側板位置決定のためにわれわれが行っている方法 を紹介するとともに，本法を行った際の下䫇枝の位置変 化を測定した結果を報告した。

本論交の要旨は, 第 29 回日本口腔外科学会（昭和59年 於札幌）にて発表した。

\section{引用 文 献}

1) 三村 保, 大枝直澍, 他：下䫇骨に拉外る骨接 合妏じによる固定について。日外誌 28 : 849-857 1982.

2) Spiessle, B.: Rigid internal fixation after sagittal osteotomy of the ascending ramus. In. B. Spiessl(ed.), New concept in maxillofacial bone surgery. Springer-Verlag, Berlin, 1976, p 115-122.

3) R. Schmoker: Preoperative planning of Sagittal split osteotomy of the ascending mandibular Ramus (Simulography) In. B. Spiessle (ed.), New concept in maxillofacial bone surgery. Springer-Verlag, Berlin, 1976, p 98108.

4) Souyris, F.: Sagittal splitting and bicortical screw fixation of the ascending ramus. J Maxillofac. Surg 6: 198-203 1978.

5）松浦正朗, 瀬戸皖一, 他：下顎枝矢状分割齐 止的固定法に批ける下顎枝外側骨片の位置復元 の開発. 日口外誌 30：615-621 1984 .

6）瀬戸皖一，岡田とし江，他：下䫇枝矢状分割法 へのセラミックネジ止め固定法の応用. 日口外 誌 29: 1671-1679 1983.

7) 道健一, 吉田厷, 他; 下䫇枝斜矢状切巏咬 合改善術とその術後評価. 日外誌 $31: 1569-$ 15761985.

8）饭塚忠彦, 藤田茂之, 他 . 各種顎变形症に対寸 る外科的矯正術術中出血量と手術时間について の検討。日口外誌 28：1956-1963 1982. 